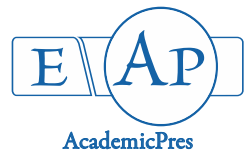

\title{
Microbiological Assessment of Pollution Level of Agba Dam, in Ilorin Metropolis, Nigeria
}

\author{
Toyin Olayemi AGBABIAKA*, Frank Olakunle OTUYELU \\ University of Ilorin, Department of Microbiology, Ilorin, \\ Nigeria; agbabiaka.to@unilorin.edu.ng (*correspondingauthor);frankotuyelu1@gmail.com
}

\begin{abstract}
Agba Dam, which is an important source of raw water used in treatment of water for supply of potable water in Ilorin Metropolis, was evaluated for presence of bacteria, pollution level and potability. Samples were collected from four points along the course of the dam. Bacteria isolated included Enterobacter aerogenes, Salmonella enteritidis, Shigella dysenteriae, Proteus vulgaris, Enterobacter cloacae and Escherichia coli using selective media and Microbact identification system. The $\mathrm{pH}$ of the water samples ranged between 7.51-7.90, temperature ranged between $22-29^{\circ} \mathrm{C}$, total hardness ranged between $0.38-0.49$ $\mathrm{gm} / \mathrm{l}$, total suspended solid ranged between $0.17-0.25 \mathrm{mg} / \mathrm{l}$, total solid ranged between $0.86-0.99 \mathrm{mg} / \mathrm{l}$, dissolved solid ranged between $0.61-0.78 \mathrm{mg} / \mathrm{l}$. The average total bacterial and coliform counts ranged from $1.0 \times 10^{2}-1.54 \times 10^{2} \mathrm{cfu} / \mathrm{ml}$ and $1.1 \times 10^{1}$ $5.9 \times 10^{1} \mathrm{cfu} / \mathrm{ml}$ respectively. The presence of these pathogenic microorganisms showed high level of contamination of the raw water body. This might be a consequence of the human activities around the water body, thus posing a great health risk if not properly and adequately treated.
\end{abstract}

Keywords: dam; microorganisms; potability; raw water; treatment

\section{Introduction}

Water is essential to life, water covers over $70 \%$ of the earth's surface (2010). Over $90 \%$ of the weight of any living cell is composed of water and all of the chemical reactions associated with life are based on this compound (Magombo, 2010). An adequate, safe and accessible water supply must be available to all. Improving access to safe drinking-water can result in significant benefits to health. Every effort should be made to achieve a drinking water quality as safe as possible (WHO, 2008). Water regulates the temperature of the body and plays a role in the acid-base balance of the body fluid (Yang et al., 2009).

Water is regarded as contaminated when it contains pathogenic microorganisms or dangerous chemical agents. Such water may be pleasant in taste, odour and appearance. Polluted water may be coloured and may or may not contain chemical or organic materials, which makes it unpleasant for drinking and other uses (Ashbolt, 2015). Pollution of water, either drinking or recreational, causes many deaths and much illness among rural and urban residents all over the world. From a public health or ecological view, a pollutant is any biological, physical, or chemical substance that in identifiable excess is known to be harmful to other desirable living organisms (Cabral, 2010).

Microbial contamination of water due to pathogenic organisms is another important problem for the water quality management and another important factor of river water pollution. These pathogenic microorganisms comes from the faeces of human and warm blooded animals which are introduced to river water through the release of effluent from waste water, house drainage and surface runoff. Contamination of river water due to pathogenic microorganisms is considered as an indicator risk of pathogeninduced illnesses in humans (Noble et al., 2004).

Total coliform comprises bacterial species of faecal origin as well as other bacterial groups. The coliforms are indicative of the general hygienic quality of the water and potential risk of infectious diseases from water. High faecal coliform and total coliform counts in water are usually manifested in the form of diarrhea and sometimes by fever and other secondary complications (Sivaraja and Nagarajan, 2014).

Enterobacteriaceae is one of the most widely studied families of bacteria. The members of this family are gram negative, rod shaped, non-sporulating and facultative anaerobes. Some members of this family are able to ferment lactose with the production of acid and gas. These are called coliforms. Examples of coliform are E. coli, Klebsiella, Enterobacter, Citrobacter etc. However, others do not ferment lactose and includes Shigella sp. and Salmonella sp. Most of the members of this family Enterobacteriaceae cause infection in their host (Sule and Agbabiaka, 2008).

Received: 17 Jul 2018. Received in revised form: 22 Jan 2019. Accepted: 20 Mar 2019. Published online: 21 Mar 2019. 
52

\section{Materials and Methods}

\section{Sample collection}

Water samples from Agba dam were collected once in a week for four weeks at four different points. The sterile sampling bottle with a rope tied around the neck was dipped into the water source; water was allowed to flow into the bottle and closed immediately. The samples were carried in a covered ice bag container and were immediately transported and analysed in the laboratory not more than 1 hour (Fawole and Oso, 2007).

\section{Culture media}

MacConkey agar was used for the enumeration of total coliform and Eosin Methylene Blue (EMB) which is a differential medium for the isolation of E. coli. MacConkey broth was used for the enumeration of coliforms in the water sample. Each of the medium was prepared according to manufacturer's instruction.

\section{Determination of physicochemical parameters}

Determination of $p H$

A $\mathrm{pHep}^{\circ} \mathrm{pH}$ meter standardized with different $\mathrm{pH}$ values of 4, 7, and 9 in buffer solution, was used to determine the $\mathrm{pH}$ of the samples. Fifty $\mathrm{ml}$ of each of the samples was introduced into test tubes. The standardized $\mathrm{pH}$ meter was inserted into the samples to obtain the $\mathrm{pH}$. The determination was carried out in duplicates and the average values of the original water samples were obtained (Sule et al., 2009).

\section{Determination of temperature}

A-H-B DURAC mercury thermometer was used in measuring the temperature of the water sample collected into sampling bottles. The readings were taken when mercury level in the thermometer became steady. Duplicate readings were taken and the average of the temperature values of the water sample was obtained (Sule et al., 2009).

\section{Determination of total hardness}

About 5 drops of 25\% ammonium and 3 drops of Erichrome Black T indicator were added to $50 \mathrm{ml}$ of sample and titrated against $0.1 \mathrm{M}$ ethylene diamine tetra-acetate (EDTA). The end point was determined by carefully watching out for a change in colour from pink to green. Each of the steps was carried out in duplicate and the average total hardness was obtained. The procedure was repeated for each of the samples (Dubey and Maheshwari, 2004).

\section{Determination of total solid}

A crucible was dried in the hot air oven at $170{ }^{\circ} \mathrm{C}$ for lhour, cooled in the desiccators and weighed $\left(\mathrm{W}_{1}\right)$. After shaking the sample properly, $50 \mathrm{ml}$ was dispersed into the crucible and weighed $\left(W_{2}\right)$. The crucible and the water sample were heated to dryness and after cooling, it was weighed and the weight of crucible minus evaporated water was assigned as $\mathrm{W}_{3}$. The procedure was carried out for all the treatment at interval of 5 days (Dubey and Maheshwari, 2004). The total solid content was calculated using the formula given below:
Total solid $(\mathrm{mg} / \mathrm{ml})=\mathrm{W}_{2}-\mathrm{W}_{1} / \mathrm{W}_{1}$

$\mathrm{W}_{1}=$ Weight of crucible

$\mathrm{W}_{2}=$ Weight of crucible + water sample

$\mathrm{W}_{3}=$ Weight of crucible after drying

\section{Determination of suspended solid}

This was determined by filtration method using the Watman's filter papers. The filter paper was dried in the hot air oven at $105^{\circ} \mathrm{C}$ for 10 minutes, allowed to cool in the desiccators and weighed $\left(\mathrm{W}_{1}\right)$. The filter was folded, placed in a funnel on a conical flask; $50 \mathrm{ml}$ of the sample was poured into the filter paper and then allowed a drain. The filter paper was re-dried in the oven at $105{ }^{\circ} \mathrm{C}$ for 10 minutes, cooled then re-weighed $\left(\mathrm{W}_{2}\right)$. The procedure was repeated for each of the sample and the results were obtained (Dubey and Maheshwari, 2004). The total suspended solid was obtained using the formula given below:

$\mathrm{SS}(\mathrm{mg} / \mathrm{ml})=\mathrm{W}_{2}(\mathrm{mg} / \mathrm{ml})-\mathrm{W}_{1}(\mathrm{mg} / \mathrm{ml})$

$\mathrm{SS}=$ Suspended solid

$\mathrm{W}_{2}=\mathrm{W}$ eight of residue + filter paper

$\mathrm{W}_{1}=$ Weight of filter paper.

\section{Determination of dissolved solid}

This was carried out by subtracting the value of suspended solid obtained for each sample from the value of total solid obtained for each sample (Dubey and Maheshwari, 2004). The dissolved solid was obtained using this formula;

Dissolved Solid $(\mathrm{mg} / \mathrm{ml})=\mathrm{TS}(\mathrm{mg} / \mathrm{ml})-\mathrm{SS}(\mathrm{mg} / \mathrm{ml})$.

\section{Microbiological analysis}

Determination of Most Probable Number (MPN)

This was done to confirm whether or not the water contained lactose-fermenting, gas-producing bacteria. Nine McCartney bottles containing sterile MacConkey broth and inverted Durham tubes in a 3-3-3 tube regimen were set for each sample according to the size of the water sample, i.e. $10 \mathrm{ml}, 1 \mathrm{ml}$ and $0.1 \mathrm{ml}$ respectively. For the $10 \mathrm{ml}$ sample, double strength MacConkey broth was used, $0.1 \mathrm{ml}$ water sample was dispersed into each bottle $(1,2,3) ; 1 \mathrm{ml}$ in each bottle $(4,5$, and 6$)$ and $10 \mathrm{ml}(7,8,9)$. After inoculation, the bottles were corked and incubated at $37^{\circ} \mathrm{C}$ for 24 hours for gas production and lactose fermentation. Production of gas in the Durham tubes and colour change from red to yellow (acid production) confirmed the presence of coliform in the samples (Fawole and Oso, 2007).

\section{Confirmatory test for coliform bacteria}

This test was meant for differentiating the coliform from that of non-coliform. The EMB agar was inoculated with culture from previous positive bottles with gas production for $37^{\circ} \mathrm{C}$ for 24 hours. Observe plates for coliform colonies. If $E$. coli is present, the colonies appear green with a metallic sheen. Colonies of Enterobacter aerogenes, if present, appear purple and tend to coalesce. These observations on the EMB plate give a positive confirmed test for coliforms (Fawole and Oso, 2007).

Completed test for coliform bacteria

Confirmed coliform colonies from the confirmatory test 
plate were used to inoculate a tube of lactose broth with Durham tube and nutrient agar slant. Both the slant and tube were incubated at $44^{\circ} \mathrm{C}$ for 48 hours. Lactose broth culture was observed for gas production (Fawole and Oso, 2007).

\section{Characterization and identification of bacterial isolates}

The characterization and identification of bacterial isolates were based on the biochemical tests and Microbact Identification System. The Microbact biochemical identification kit was used for the identification of Gram negative bacteria; $24 \mathrm{E}$ set which can identify both oxidasepositive and oxidase-negative bacteria was used. For the identification procedure, an $18-24$ hours old culture of the isolates was prepared on nutrient agar and $0.85 \%$ normal saline solution was also prepared and dispensed into McCartney bottles and 1-3 colonies from the young culture of the bacterial isolates was then picked and emulsified into the $5 \mathrm{ml}$ of the sterile normal saline prepared and shaken thoroughly to form a homogenous suspension. Using a sterile pipette, 4 drops from this emulsified suspension was added aseptically into each well. After inoculation, wells 1 , $2,3,20$ and 24 were overlaid with mineral oil for oxidasenegative organisms while wells $1,2,3$ and 24 were overlaid with mineral oil for oxidase-positive organisms and afterwards incubation was done for 18-24 hours according to the Oxoid kit instructions. The results were read as stipulated in the kit manual after which the octal and nine digits code obtained was run on the identification software to get the most probable identity of the Gram negative bacteria.

\section{Results}

\section{Physicochemical analysis}

As shown in Figs. 1 to 6, temperature ranged from $22^{\circ} \mathrm{C}$ to $29^{\circ} \mathrm{C}$ throughout the samples, $\mathrm{pH}$ ranged from 7.51 to 7.90, total hardness ranged from $0.38-0.49 \mathrm{mg} / \mathrm{l}$, suspended solid ranged from $0.17-0.25 \mathrm{mg} / \mathrm{l}$, total solid ranged from $0.86-0.99 \mathrm{mg} / \mathrm{l}$, total dissolved solid ranged from $0.61-0.80 \mathrm{mg} / \mathrm{l}$.

\section{Microbiological analysis}

Tables 1, 2 and 3 below showed the average total bacterial and coliform counts ranged from $1.0 \times 10^{2} \mathrm{cfu} / \mathrm{ml}$ $1.54 \times 10^{2} \mathrm{cfu} / \mathrm{ml}$ and $1.1 \times 10^{1} \mathrm{cfu} / \mathrm{ml}-5.9 \times 10^{1} \mathrm{cfu} / \mathrm{ml}$. Table 3 showed the result for the Most Probable Number (MPN).

\section{Isolates identification}

Microorganisms identified included Enterobacter aerogenes (87.99\%), Salmonella enteritidis (98.99\%), Shigella dysenteriae (89.22\%), Proteus vulgaris (97.89\%), Enterobacter cloacae (92.89), Escherichia coli (99.99\%).

Table 1. Total bacterial count

\begin{tabular}{|c|c|c|c|c|c|c|c|c|c|c|c|c|}
\hline \multirow{4}{*}{$\begin{array}{c}\text { Sampling } \\
\text { Point }\end{array}$} & \multicolumn{12}{|c|}{ Total Bacterial Count $\left(\mathrm{n} \times 10^{4} \mathrm{cfu} / \mathrm{ml}\right)$} \\
\hline & \multicolumn{12}{|c|}{ Weeks } \\
\hline & \multicolumn{3}{|c|}{1} & \multicolumn{3}{|c|}{2} & \multicolumn{3}{|c|}{3} & \multicolumn{3}{|c|}{4} \\
\hline & $\mathrm{P}_{1}$ & $\mathrm{P}_{2}$ & $\mathrm{P}_{\mathrm{av}}$ & $\mathrm{P}_{1}$ & $\overline{\mathrm{P}_{2}}$ & $\mathrm{P}_{\mathrm{av}}$ & $\overline{\mathrm{P}_{1}}$ & $\mathrm{P}_{2}$ & $\mathrm{Pav}_{\mathrm{av}}$ & $\mathrm{P}_{1}$ & $\mathrm{P}_{2}$ & $\mathrm{P}_{\mathrm{av}}$ \\
\hline A & 1.22 & 1.48 & 1.35 & 1.84 & 1.24 & 1.54 & 1.36 & 1.12 & 1.24 & 1.73 & 1.35 & 1.54 \\
\hline B & 1.63 & 1.37 & 1.50 & 1.45 & 0.91 & 1.18 & 1.21 & 1.02 & 1.12 & 1.49 & 1.27 & 1.38 \\
\hline $\mathrm{C}$ & 1.55 & 0.97 & 1.26 & 1.18 & 0.88 & 1.03 & 1.33 & 1.51 & 1.42 & 0.84 & 1.16 & 1.00 \\
\hline $\mathrm{D}$ & 1.61 & 1.08 & 1.35 & 1.28 & 1.54 & 1.41 & 1.42 & 1.18 & 1.30 & 1.37 & 1.02 & 1.20 \\
\hline
\end{tabular}

Keys: P1 (plate 1), P2 (duplicate plate), $P_{a v}($ mean value).

Table 2. Total coliform count

\begin{tabular}{|c|c|c|c|c|c|c|c|c|c|c|c|c|}
\hline \multirow{4}{*}{ Sampling Point } & \multicolumn{12}{|c|}{ Total Coliform Count $\left(\mathrm{x} 10^{3} \mathrm{cfu} / \mathrm{ml}\right)$} \\
\hline & \multicolumn{12}{|c|}{ Week } \\
\hline & \multicolumn{3}{|c|}{1} & \multicolumn{3}{|c|}{2} & \multicolumn{3}{|c|}{3} & \multicolumn{3}{|c|}{4} \\
\hline & $\mathrm{P}_{1}$ & $\mathrm{P}_{2}$ & $\mathrm{P}_{\mathrm{av}}$ & $\mathrm{P}_{1}$ & $\mathrm{P}_{2}$ & $\mathrm{P}_{\mathrm{Pav}}$ & $\mathrm{P}_{1}$ & $\mathrm{P}_{2}$ & $\mathrm{P}_{\mathrm{av}}$ & $\mathrm{P}_{1}$ & $\mathrm{P}_{2}$ & $\mathrm{P}_{\mathrm{av}}$ \\
\hline $\mathrm{A}$ & 6.1 & 4.7 & 5.4 & 2.7 & 1.7 & 2.2 & 3.8 & 3.5 & 3.7 & 1.4 & 1.8 & 1.6 \\
\hline B & 3.4 & 2.1 & 2.8 & 4.7 & 3.8 & 4.3 & 4.1 & 4.5 & 4.3 & 3.5 & 2.7 & 3.1 \\
\hline $\mathrm{C}$ & 1.3 & 9 & 1.1 & 6.7 & 5.1 & 5.9 & 2.6 & 3 & 2.8 & 1.6 & 1.9 & 1.8 \\
\hline $\mathrm{D}$ & 2.3 & 1.8 & 2.1 & 5.3 & 4.9 & 5.1 & 1.9 & 1.5 & 1.7 & 4.5 & 3.3 & 3.9 \\
\hline
\end{tabular}

Keys: $\mathrm{P}_{1}$ (plate 1), $\mathrm{P}_{2}$ (duplicate plate), $\mathrm{P}_{a v}($ mean value).

Table 3. Most Probable Number (MPN) of coliform

\begin{tabular}{ccccc}
\hline \multirow{2}{*}{ Sampling Point } & \multicolumn{4}{c}{ MPN Index per 100ml } \\
\cline { 2 - 5 } & \multicolumn{4}{c}{ Weeks } \\
\cline { 2 - 5 } & 1 & 2 & 3 & 28 \\
A & $2100+$ & 1100 & 28 & 23 \\
B & 460 & 1100 & 460 & 1 \\
C & 1 & 460 & 21 & 21 \\
D & 7 & & 9 & 4 \\
\hline
\end{tabular}


54

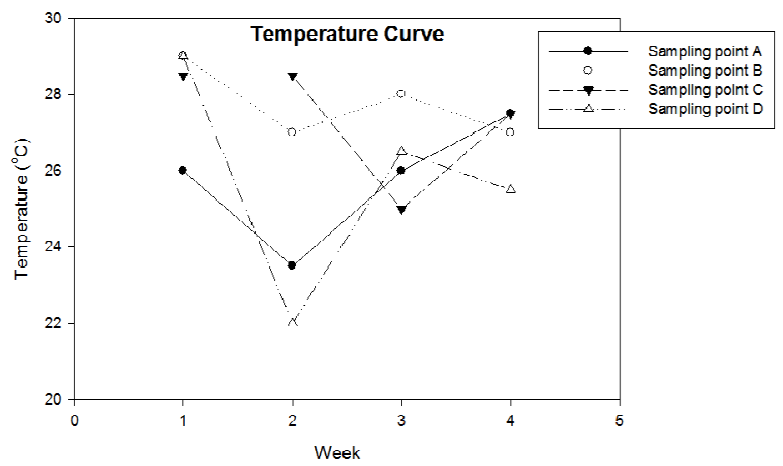

Fig. 1. Temperature of water samples

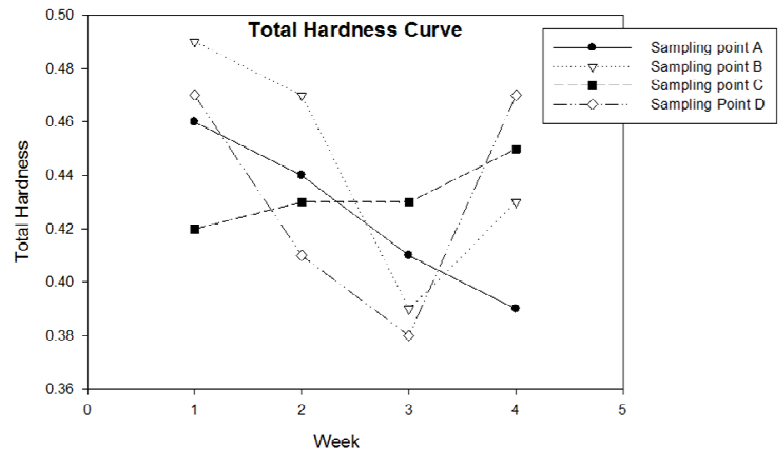

Fig. 3. Total hardness of water samples

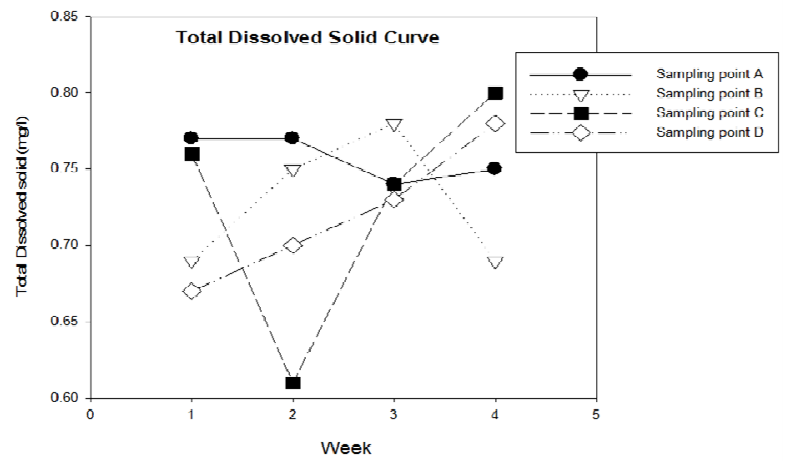

Fig. 5. Total dissolved solid of water samples

\section{Discussion}

Temperature and $\mathrm{pH}$ are important factors influencing the growth of organisms in an aquatic environment. The $\mathrm{pH}$ value that support the growth of the Enterobacteriaceae usually ranged from $5.5-8.0$ and temperature from $18^{\circ} \mathrm{C}$ to $47^{\circ} \mathrm{C}$. In this study, temperature ranged from $22^{\circ} \mathrm{C}$ to 29 ${ }^{\circ} \mathrm{C}$ while $\mathrm{pH}$ value ranged from 7.51 and 7.90 . This is in accordance with what was obtained by Singh and Sao (2015) in their study for both temperature and $\mathrm{pH}$ values at 20.5 to $21.4^{\circ} \mathrm{C}$ and 7.3 to 7.9 respectively.

Total hardness ranged from $0.38-0.49 \mathrm{mg} / \mathrm{l}$, suspended solid ranged from $0.17-0.25 \mathrm{mg} / \mathrm{l}$, total solid ranged from 0.86-0.99 $\mathrm{mg} / \mathrm{l}$, total dissolved solid ranged from 0.61-0.80 $\mathrm{mg} / \mathrm{l}$. supporting this results was a research carried out by Singh et al. (2004) who reported a total hardness value of $0.58 \mathrm{mg} / \mathrm{l}$ total hardness in a research work done on Gomit

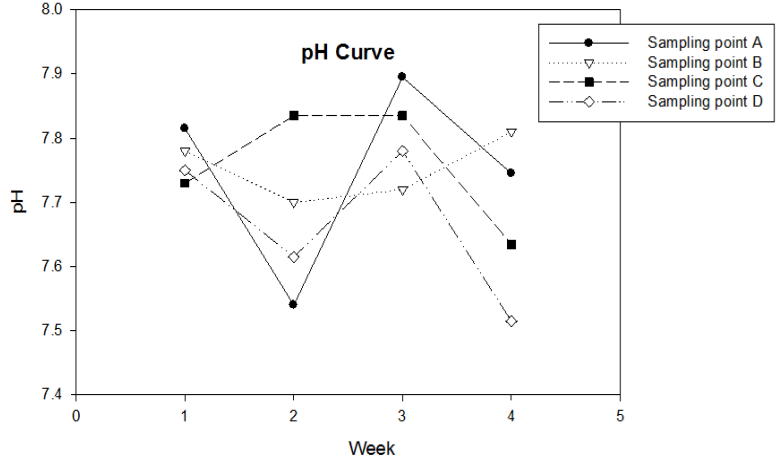

Fig. 2. $\mathrm{pH}$ of water samples

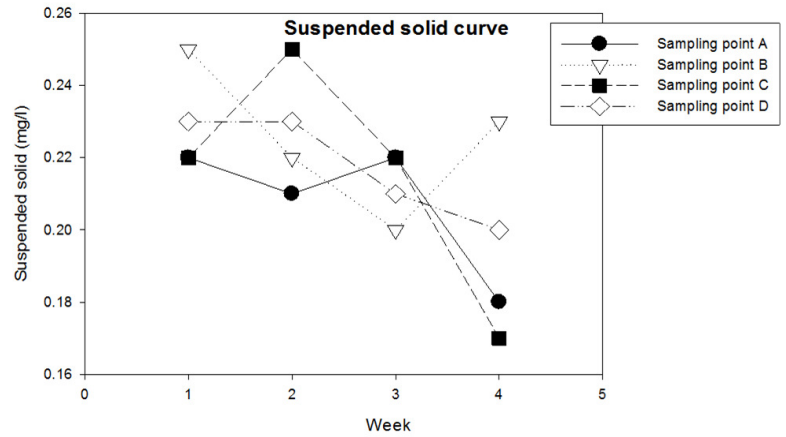

Fig. 4. Suspended solid of water samples

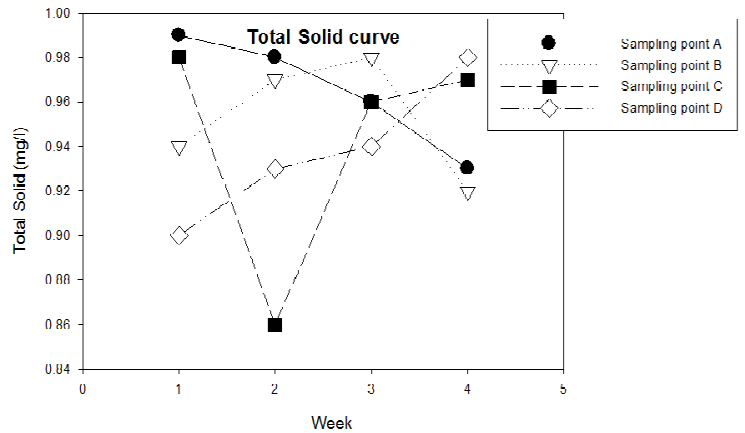

Fig. 6. Total solid of water samples

river, India. Supporting this result was a research carried out by Bhandari and Nayal (2008), where they reported the total dissolved solid and total suspended solid from Kosi river water, Uttarakhand ranged from $24.3-54.3 \mathrm{mg} / \mathrm{l}$ and $4.3-10.66 \mathrm{mg} / \mathrm{l}$ respectively.

Shigella sp. obtained in this study was also obtained in similar research conducted by Sharma et al. (2010) in a research work on phenotypic and genotypic characterization of Shigella spp. with reference to its virulence genes and antibiogram analysis from river Narmada isolating different species of Shigella from the river. Kinge and Mbewe (2010) also isolated Shigella sp. in a similar research on the characterization of Shigella sp. from river catchments in the North West province of South Africa.

E. coli obtained in this study was also reported in a similar research by Koczura et al. (2012) from different 
sources including river water.

Okonko et al. (2008) reported the isolation of Proteus sp., Enterobacter aerogenes, E.coli, from water samples used for domestic purposes in the South-Western part of Nigeria which is similar to those obtained in this study.

\section{Conclusions}

Agba Dam, a major raw water source used for treatment of public water supply contains members of Enterobacteriaceae some of which are pathogenic thus posing a great risk on human's health if not properly treated. The presence of these organisms could be as a result of human activities in and around the dam.

\section{Recommendation}

Proper and adequate purification should be done on the water due to its pollution level before been distributed throughout the metropolis to avoid the recurrence of outbreak of gastroenteritis due to faulty filtration beds and shortage of chlorine experienced in the past.

\section{References}

Ashbolt NJ (2015). Microbial contamination of drinking water and human health from community water system. Current Environmental Health Report 2(1):95-106.

Cabral JPS (2010). Water microbiology: bacterial pathogens and water. International Journal of Environmental Research and Public Health 7(10):3657-3703.

Dubey RC, Maheshwari DK (2004). Practical microbiology. S. Chad \& CompanyLtd. New Delhi, pp 162-301.

Fawole MO, Oso BA (2007). Laboratory manual of microbiology. Spectrum Books, Nigeria Limited, Ibadan, pp 78-79.

Kinge CW, Mbewe M (2010). Characterization of Shigella sp. isolated from river catchments in the North West province of South Africa. South Africa Journal of Science 106(11-12):1-4.

Koczura R, Mokracka J, Jabłońska L, Gozdecka E, Kubek M, Kaznowski A (2012). Antimicrobial resistance of integron-harboring Escherichia coli isolates from clinical samples, wastewater treatment plant and river water. Science of the Total Environment 414:680-685.

Magombo PU, Kosamu M, Bobby I (2010). Challenges of water accessibility in the urban centres of Malawi: A case study of Blantyre City. African Journal of Environmental Science and Technology 10(10):380-385.
Noble RT, Lee IM, Schiff KC (2004). Inactivation of indicator microorganisms from various sources of faecal contamination in seawater and freshwater.Journal of Applied Microbiology 96(3):464-476.

Okonko IO, Adejoye OD, Ogunnusi TA, Fajobi EA, Shittu OB (2008). Microbiological and physicochemical analysis of different water samples used for domestic purposes in Abeokuta and Ojota, Lagos State, Nigeria. African Journal of Biotechnology 7(5):617-621.

Sharma A, Singh SK, Bajpai D (2010). Phenotypic and genotypic characterization of Shigella spp. with reference to its virulence genes and antibiogram analysis from river Narmada. Journal of Microbiological Research 165(1):33-42.

Singh KP, Malik A, Mohan D, Sinha S (2004). Multivariate statistical techniques for the evaluation of spatial and temporal variations in water quality of Gomti River (India) - a case study. Water Research 38(18):3980-3992.

Singh R, Sao S (2015). Evaluation of water quality by physicochemical parameters, heavy metal and use of metal resistant property of bacteria for bioremediation of heavy metals. World Journal of Environmental Pollution 5(2):23-28.

Sivaraja R, Nagarajan K (2014). Level of indicator microorganisms (total and fecal coliforms) in surface waters of rivers Cauvery and Bhavani for circuitously predicting the pollution load and pathogenic risks. International Journal of Pharm Tech Research 6(2):455-461.

Sule IO, Oyeyiola GPO, Agbabiaka TO (2009). Comparative bacteriological analysis of chlorinated and dechlorinated pipeborne water. International Journal of Biological Science 1(1):93-98.

Sule IO, Agbabiaka TO (2008). Antibacterial effect of some plant extracts on selected Enterobacteriaceae. Ethnobotanical Leaflets 12:1035-1042.

WHO (World Health Organization) (2008). Guidelines for drinkingwater quality, Incorporating 1st and 2nd Addenda, Volume 1, Recommendations.3rded. WHO; Geneva, Switzerland, pp 229-234.

World Health Organisation, United Nations Children's Fund (2010). Progress on sanitation and drinking-water update. WHO; Geneva, Switzerland, pp 60.

Yang JN, Chen JF, Fredholm BB (2009). Physiological roles of $A_{1}$ and $A_{2 A}$ adenosine receptors in regulating heart rate, body temperature, and locomotion as revealed using knockout mice and caffeine. American journal of Physiology 296(4):1141-1149. 